\title{
殺菌剂の最終散布時期がナシうどんこ病の発病に 及ぼす影響
}

\author{
新田浩通 \\ （広島県立農業技術センター果樹研究所）
}

\begin{abstract}
広島県のナシ栽培における “幸水”の比率は約 $50 \%$ で多くは無袋栽培されている。筆者ら ${ }^{21}$ は，無袋栽培の ナシ ‘幸水’において, 収穫までの殺菌剤の散布回数 を合理的に削減する目的で，ナシ輸紋病について，い つの時期まで防除を行う必要があるかを検討し，果実 における最終散布時期は満開後95日（収穫前 1 か月） 頃で良いことを見いだした。しかし，本県のナシ産地 では, 満開後95日以降にも殺菌剂を散布している園地 が多く, 収穫前の殺菌剤の散布を早い時期に切り上げ ることにより，他病害の多発を招くことが賏念された。 このうち, ナシうどんこ病は, 夏季から秋季にかけて 葉裏に発病するが, 果実の被害がないことや, 治療効 果の高い殺菌剤が数多く登録を得ていることなどから， 防除対象の病害としては軽視されがちである。しかし， 近年, 秋季の発病が増加携行にあるうえ, 本病に激し く罹病した場合には早期落葉の原因となり, 果実品質 や樹勢に悪影響を及ぼすことが知られている"。このた め, 殺菌剤の最終散布時期がナシうどんこ病の発病に 及ぼす影響を調查し，若干の知見を得たので報告する。
\end{abstract}

\section{材料及び方法}

試験は，1996年と1997年に広島県立農業技術センター 果樹研究所内で平棚栽培しているナシ ‘幸水” 26 27

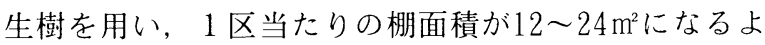
うに処理区を設定した。薬剤は, 満開後 4〜39日の間, 殺菌剂を 4 回散布し, その後, 満開後54 110日の間は 同一の殺菌剂を約 2 週間毎に散布し, 最終散布時期の 異なる 5 区を設定し，両年の各処理区は異なる樹を用 いた。殺菌剂は，1996年にはキャプタン・ベノタル剂 500倍液，1997年にはイミノクタジンアルベシル酸塩剂 1000倍液を供試した。処理区並びに薬剂散布の実績は, 第 1 表と第 2 表に示した。1996年には，9月30日（満 開後155日）に 1 区300葉を対象に発病葉率を調査し,
1997年には 8 月 21 日〜 10月23日（満開後127〜190日） の間に，あらかじめラベルをとりつけた 1 区20新梢（約 450葉）を対象として, 約10日間隔で, 発病葉率, 子の う款形成葉率及び落葉率を調査した。なお，供試樹の 果実は, 満開後123〜124日に収穫した。

\section{結果及び考察}

1996年の試験における9月30日時点の発病葉率は, 満開後55日に殺菌剂を最終散布したA 区で $48 \%$ と最も 高い值を示し, 次いで, 満開後64日に最終散布したB 区で18\%，満開後79日に最終散布したC 区で9.3\%の順 であり，この期間内では最終散布を早い時期に切り上 げた区ほど多発傾向にあった。一方，満開後94日に最 終散布したD区の発病葉率は3.3\%であったのに対し， 満開後107日に最終散布した E 区の発病率は $6 \%$ であ り，両区間の差異は認別れなかった（第 1 表）。

ナシうどんこ病は，秋季に形成された子のう殼が樹 上に残った場合に，重要な第一伝染源となることが知 られている”。また，多発した場合には，早期落葉し樹 勢に影響を及ぼすことがあることから，1997年にも同 様の試験を実施し, 発病葉率, 子のう殼形成葉率及び 落葉率の推移を調查した。その結果, 満開後54日に殺 菌剂を最終散布した A 区では 9 月 1 日に初発を認め, 9 月11日頃から発病葉率が急增した。満開後 62 日に最 終散布した B 区と満開後78日に最終散布したC区では， 9月11日に初発を認めたが，B区では 9 月30日頃から， C区では10月23日頃から発病葉率が急増した（第 1 図）。 これら 3 区は，いずれの区も 9 月30日頃から子のう款 の形成が認められ，10月12日頃から急增したが，10月 23日の調査では, 発病葉率と同様に最終散布を早い時 期に切り上げた区ほど多発傾向にあった（第 2 図）。一 方, 満開後94日に最終散布したD区と満開後110日に最 終散布した E区では，9月30日に初発を認め，この時

Hiromichi Nitta (Fruit Tree Res. Inst., Hiroshima Pref. Agr. Res. Ctr.) : Timing of final application of fungicide influencing the occurrence of powdery mildew of Japanese pear.

2000年 1 月 26 日受理 
点では両区の発病葉率に顕著な差異はなかったが, 10 月23日の調査ではD区が $\mathrm{E}$ 区のほぼ 2 倍の発病となっ た (第 1 図)。また, 両区の子のう殼形成葉率も発病葉 率の推移とほぼ同様の傾向が認められた（第 2 図）。な お，落葉率は，A区では10月12日以降に多発傾向にあ ったものの，他の区間に差異は認められなかった。

以上の結果，両年とも 9 月30日（満開後155～167日） の発病葉率は，D区と E区の間に顕著な差異を認めな かったため, 最終防除を満開後95日頃としても満開後 120～130日頃に収穫される“幸水”においては, 当年 の果実品質に悪影響を及ぼすとは考えられない。しか し，10月下旬の子のう殻形成葉率は D 区が $\mathrm{E}$ 区に比べ 高かったことから, 翌年への伝染源量を増加させる可 能性がある。このため, 最終防除を満開後95日頃とす る場合には, 落葉前の葉における子のう殻の形成を確

\section{第 1 表 1996年のナシうどんこ病防除試験における殺 菌剂の散布実績と発病葉率}

\begin{tabular}{|c|c|c|c|c|c|c|c|c|c|}
\hline \multirow{2}{*}{$\begin{array}{l}\text { 処 } \\
\text { 理 } \\
\text { 区 }\end{array}$} & \multicolumn{4}{|c|}{ 散布月日 } & \multicolumn{4}{|c|}{ (満開後日数) } & \multirow{2}{*}{$\begin{array}{l}\text { 発病 } \\
\text { 葉率"2 }\end{array}$} \\
\hline & $\begin{array}{l}5 / 2 \\
(4)\end{array}$ & $\begin{array}{l}5 / 13 \\
(15)\end{array}$ & $\begin{array}{l}5 / 27 \\
(29)\end{array}$ & $\begin{array}{l}6 / 3 \\
(36)\end{array}$ & $\begin{array}{l}6 / 22 \\
(55)\end{array}$ & $\begin{array}{l}7 / 1 \\
(64)\end{array}$ & $\begin{array}{l}7 / 16 \\
(79)\end{array}$ & $\begin{array}{l}7 / 318 / 13 \\
(94)(107)\end{array}$ & \\
\hline $\mathrm{A}$ & $\mathrm{T}$ & $\mathrm{D}$ & $\mathrm{P}$ & B & 0 & & & & $48.0 \%$ \\
\hline B & $\mathrm{T}$ & $\mathrm{D}$ & $\mathrm{P}$ & B & 0 & 0 & & & 18.0 \\
\hline $\mathrm{C}$ & $\mathrm{T}$ & $\mathrm{D}$ & $\mathrm{P}$ & B & 0 & 0 & 0 & & 9.3 \\
\hline D & $\mathrm{T}$ & $\mathrm{D}$ & $\mathrm{P}$ & B & 0 & 0 & 0 & 0 & 3.3 \\
\hline $\mathrm{E}$ & $\mathrm{T}$ & $\mathrm{D}$ & $\mathrm{P}$ & B & 0 & 0 & 0 & 0 & 6.0 \\
\hline
\end{tabular}

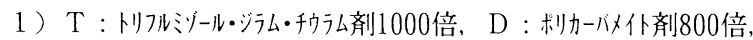

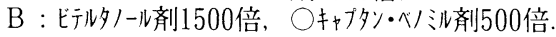

2) 9 月30日調査.

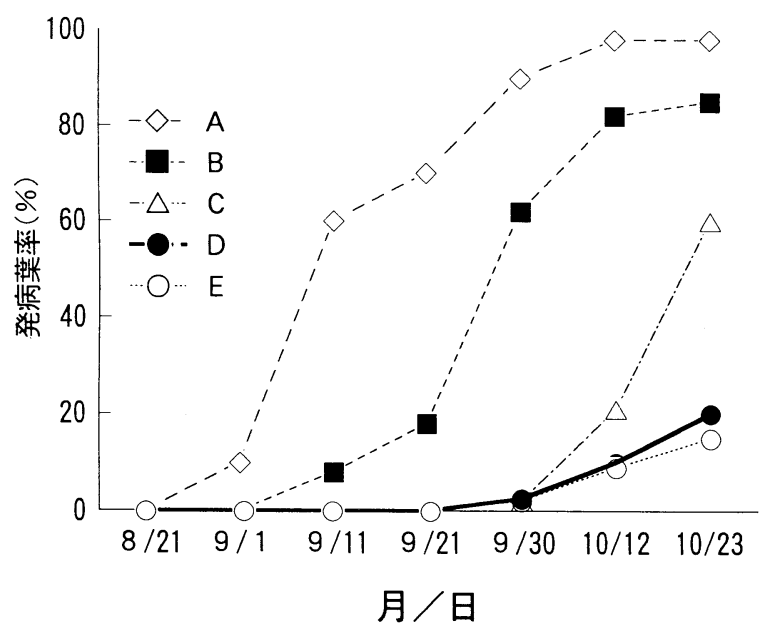

第 1 図 発病葉率の推移 (1997年)

注） $\mathrm{A} \sim \mathrm{E}:$ 処理区（第 2 表）
認し, 多発園では, 冬季の粗皮剥ぎを徹底し樹上に残 る子のう款の量を減少させたり, 翌春の子のう胞子の 飛散が始まる時期, すなわち, 平均気温が $20^{\circ} \mathrm{C}$ 示す 時期 ${ }^{3)}$ に本病に効果の高い殺菌剂を散布するなどの防除 対応を行うことが望ましい。

\section{引用文献}

1) 北島博 (1989) 果樹病害各論. 養賢堂, 東京, pp. $253-255$.

2 ）新田浩通 - 中元勝彦 - 小笠原静彦（1997）日植病 報 $63: 516$. (講要)

3 ）友久武彦・今村昭二（1959）日植病報 $24: 18$. (講要)

4 ）友久武彦・今村昭二（1961）日植病報 $26: 60$. (講要)

\section{第 2 表 1997年のナシうどんこ病防除試験における殺 菌剂の散布実績}

\begin{tabular}{cccccccccc}
\hline & \multicolumn{10}{c}{ 処 } & \multicolumn{10}{c}{ 散布月日 (満開後日数) ${ }^{1)}$} \\
\cline { 2 - 10 } 区 & $4 / 24$ & $5 / 1$ & $5 / 16$ & $5 / 25$ & $6 / 9$ & $6 / 17$ & $7 / 3$ & $7 / 19$ & $8 / 4$ \\
& $(8)$ & $(15)$ & $(30)$ & $(39)$ & $(54)$ & $(62)$ & $(78)$ & $(94)$ & $(110)$ \\
\hline $\mathrm{A}$ & $\mathrm{Z}$ & $\mathrm{T}$ & $\mathrm{P}$ & $\mathrm{M}$ & $\bigcirc$ & & & & \\
$\mathrm{B}$ & $\mathrm{Z}$ & $\mathrm{T}$ & $\mathrm{P}$ & $\mathrm{M}$ & $\bigcirc$ & $\bigcirc$ & & & \\
$\mathrm{C}$ & $\mathrm{Z}$ & $\mathrm{T}$ & $\mathrm{P}$ & $\mathrm{M}$ & $\bigcirc$ & $\bigcirc$ & $\bigcirc$ & & \\
$\mathrm{D}$ & $\mathrm{Z}$ & $\mathrm{T}$ & $\mathrm{P}$ & $\mathrm{M}$ & $\bigcirc$ & $\bigcirc$ & $\bigcirc$ & $\bigcirc$ & \\
$\mathrm{E}$ & $\mathrm{Z}$ & $\mathrm{T}$ & $\mathrm{P}$ & $\mathrm{M}$ & $\bigcirc$ & $\bigcirc$ & $\bigcirc$ & $\bigcirc$ & $\bigcirc$ \\
\hline
\end{tabular}

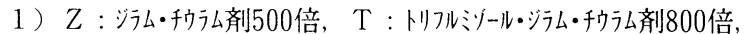
$\mathrm{P}:$ 㐜力ーハ仆剂800倍，M：千內ファネートメ手剂1500倍, ○: 隹ノク多シアルベル酸塩剂 500 倍.

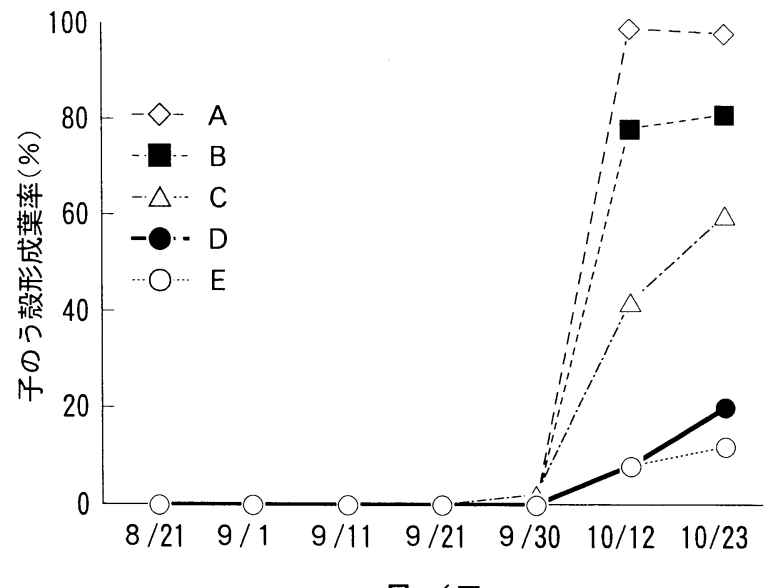

月 $/$ 日

第 2 図 子のう殻形成葉率の推移 (1997年)

注） $\mathrm{A} \sim \mathrm{E}$ : 処理区（第 2 表） 